\title{
Issues of building a model of a single executive vertical based on cooperative federalism in the aspect of municipal administration
}

\author{
Svetlana Belousova* \\ Irkutsk Scientific Center of the Siberian Branch of the Russian Academy of Sciences, Irkutsk, \\ Lermontov str. 134, 664033, Russian Federation, belousova-@mail.ru
}

\begin{abstract}
Despite the fact that the theory of endogenous growth states that economic growth is mainly the result of endogenous rather than external forces, however, the theory assigns the greatest role in this growth to investment in human capital, innovation, knowledge, etc. Because of this, the greatest attention in the aspect of economic development of territories is given to the nature of the implementation of national projects as locomotives of growth. However, their implementation at the regional and local level is hindered by the extreme lack of preparation of local and regional management in the field of their own project and organizational activities, as well as clear interaction among themselves. The solution to this problem is associated with a new stage of local self-government reform aimed at building a model of a single executive vertical based on cooperative federalism. In the article, the author analyses two main trends in the development of this model: management centralization and cooperation. It is established that centralization has affected all aspects and directions of the implementation of power, while the problem of cooperation and coordination of actions of individual branches, spheres and levels of government remains. The task is set, and certain steps are identified to implement a complementary combination of centralization and cooperation or coordination of actions at different levels of management.
\end{abstract}

The local level of government is the least regulated sphere of domestic public life from the legal, financial, organizational and other sides, despite the fact that the reform of local selfgovernment, which has been going on for almost 30 years, is only gaining momentum. The current stage of these reforms is multidimensional and is implemented through constitutional amendments, the adoption of a new version of the main law on local selfgovernment (Federal Law №131), the adoption and implementation of a large number of other federal laws (Federal Law №87-FL of 1.05.2019, Federal Law №228-FL of 26.07.2019, Federal Law №387-L of 30.10.2018, etc.), etc.

The need for a new stage of reforms is associated with the solution of a number of issues, including the problems of providing budget money for the powers of local authorities of state significance, internal initiative and many others, active participation of

* Corresponding author : belousova-@mail.ru 
local self-government bodies in the implementation of activities within the framework of national projects, etc. According to the adopted amendments to the Constitution of the Russian Federation (Article 132), local self-government bodies are part of the newly introduced unified system of public power in the Russian Federation, the essence and content of which remain open for the time being. All this suggests that the optimal model of relations between local self-government and state power, which is recognized as missing, is precisely what is planned to be created in the course of the current reforms. According to experts [1], in the course of the expected nationalization of local self-government, the basic principles and mechanisms of interaction between state authorities and local selfgovernment bodies that are absent in the laws should be established, which would make it possible to clearly formulate and link competencies (subjects of competence and powers) ISMS and their sources of funding.

The lack of this balance is recognized by many, including those who formulate the problem of limiting local self-government in modern Russian practice from a financial, economic and political point of view, justifying this, among other things, by the extremely low financial security of the powers of local self-government bodies in the amount of $23 \%$ to $40 \%$ at the level of districts and districts and from $13 \%$ to $15 \%$ at the level of rural settlements [2].

There are two main trends in overcoming this situation. On the other hand, a model of relations between the state and local self-government is being formed on the basis of cooperative federalism, which, according to experts, is an objective necessity, in the conditions of awareness of the impossibility of total differentiation of issues and subjects of competence in the management of a particular territory. Any complex decision or event in the context of federal relations requires the development of a mechanism for coordinating the positions of all parties on the principle: «a federal state is not only the division of competence and powers between federal bodies and members of the federation, but also cooperation of efforts and integration in the conduct of national affairs» [3]. In this case, we are talking about a special system of power based on cooperation, coordination of activities and joint responsibility. At the same time, the directions and forms of cooperation can be extremely diverse: bilateral or multilateral relations between the federal government and the regional, regional and local, between regional or municipal entities, etc. in the form of contracts, administrative agreements, conferences, congresses, meetings, the work of conciliation commissions, working groups, headquarters, etc.

A striking example of such complex measures is the implementation of national projects, which requires close interaction of citizens and local authorities with the state administration, which is emphasized by the President of the Russian Federation: "The absolute majority of national projects are focused on the local areas, and the role of local self-government in their implementation will increase many times....» [4]. At the same time, the forms and mechanisms of participation of the Local government bodies (LGB) in the implementation of national projects are offered [5] in a variety of ways:

- regional projects and regional programs developed with the involvement of the administrations of the municipal formation (MF);

- municipal formation agreements of the (LGB) with the state authorities of the subjects of the Russian Federation on the implementation of regional project activities;

- regional and municipal competence centres and resource centres;

- municipal project offices;

- municipal programs and action plans.

- participation in on-site inspections of the implementation of measures together with the responsible regional authorities. 
- use the institute of initiative budgeting when participating in the implementation of national projects, etc.

On the other hand, according to experts, the current trend of state-building of local selfgovernment is based on strengthening the vertical of power, an example of which is a significant increase in the role of the subjects of the Russian Federation in the organization of local self-government in their territories by granting the subjects of the Federation the right to redistribute powers on issues of local significance, which, according to experts, turns local self-government into one of the levels of executive power, while violating the constitutional principles of the organization of public power in Russia. The reasons for the redistribution of powers can be completely different reasons, including insufficient funding, lack of trained personnel, a large amount of work and other technical, organizational, political motives, which often causes a negative reaction from local authorities.

The existence of such a contradiction between local and regional development authorities lies rather in the absence of initial conditions and requirements for the functioning and development of the local community or simply the entire population of a particular territory of the country based on common national strategic norms and guidelines. The adoption of the latter is constrained by a significant socio-economic, economic-geographical, political and other asymmetry, which extends to the Russian model of federalism. The latter is identified by many as asymmetric, which manifests itself in a significant unevenness of relations between the subjects of the Federation and municipalities regarding the subjects of competence and powers. Thus, municipalities are assigned to exercise 13 state powers in the Vladimir and Novgorod Regions, 16 in the Tyumen Region, and 21 in the Krasnoyarsk Territory, etc. [6].

The source of such a provision is the legislative conditions for such a distinction, according to which the constitution defines an exhaustive list of subjects of the Federation's jurisdiction and a list of joint subjects of the Federation and the subjects of the Federation. All other subjects of competence under the «residual principle» are fixed as their own powers of the subjects of the Federation (Article 73). According to experts, the constitutional norms for the definition of powers are quite casual, since they combine and mix both powers and subjects of competence, and different types of subjects of competence: framework and competing.

Thus, the legislative mechanism for the distribution of powers between levels of government forms at least 14 types of options [7] for the distribution of powers, which creates a broad framework and rather conditional boundaries for both understanding and implementation, which requires, along with simplifying and unifying the interaction of levels of government, requires closer cooperation and coordination of the parties.

The high role of centralization of power was set with the beginning of administrative reforms [8], which determined a number of the following basic points:

- centralization is determined by a combination of objective and subjective factors and is carried out in accordance with the procedure established by law.

- the result of centralization is an increase in the degree of centralization of the public management system, minimizing the time between the adoption of a management decision and its implementation.

The processes of implementing these administrative transformations have been going on with varying success over the past twenty years and are very unbalanced. At the same time, such processes should be systemic in nature, manifesting themselves in all components of the implementation of state power.

While there are certain trends in a number of areas, there are no such measures in a number of areas yet. Thus, with regard to the centralization of public power, a number of modern main trends and their manifestations should be noted: 


\section{Political centralization}

1.1. Centralization of competences (subjects of competence and powers) at the federal level.

1.2. Centralization of powers at the regional level through mass transfer of powers from the local level to the regional level, etc.

2. Administrative centralization

2.2. Formation and mass implementation of the mechanism of double subordination in the transfer of authority to the lower level.

2.2. Creation of a unified register of the powers of the Federation and its subjects, etc.

3. Financial centralization.

3.1. The initial transfer of taxes from the territories to the federal budget, which amount to $70 \%$ of the total consolidated budget of the country.

3.2. Relative and absolute growth of inter-budget transfers with a high level of financial insolvency of sub-federal budgets.

3.3. Introduction of a single model of inter-budgetary relations for all subjects of the Federation.

3.4. Transfer from 2021 of all transactions made by participants of the budget process, including the municipal level through the Federal Treasury (FT), etc.

4. Control and analytical centralization.

4.1. Introduction of a unified national system of control over public procurement, including the level of local self-government.

4.2. Introduction of a unified information and analytical system of budget (accounting) accounting in the budget sphere, etc.

If the «presidential vertical» was built for a long time in political terms, which did not destroy the vertical of regional power, now centralization has affected all aspects and directions of the implementation of power, leaving, however, at least the formal task of ensuring its cooperation and coherence of actions. The issues of objectivity, importance, but also the problematic nature of the centralization of power are widely considered by experts, as are the current trends of evolutionary cyclicity or balancing the benefits of its centralization and decentralization. However, the emphasis only on such a footer of power does not remove the option of considering a complementary combination of centralization and cooperation, or the coordination of actions of different levels of government. It is not easy to form such an alliance due to the increased cooperation of actions based on their centralization, since this managerial goal is very multifaceted and concerns both organizational and ideological, ideological, psychological, and other aspects.

At the same time, in the functional, strategic, economic, ideological, informational, and other areas, such measures to centralize power are very limited. In addition, if at present centralization has affected many aspects and directions of the implementation of power, leaving, however, at least the formal task of ensuring its cooperation and coherence of actions. The issues of objectivity, importance, but also the problematic natures of the centralization of power are widely considered by experts, as are the current trends of evolutionary cyclicity or balancing the benefits of its centralization and decentralization. However, the focus only on such a range of power development does not remove the option of considering a complementary combination of centralization and cooperation, or coordination of actions at different levels of government. It is not easy to form such an alliance by increasing the cooperation of actions based on their centralization, since this management goal is very multifaceted and also concerns political, financial, administrative and analytical issues.

Cooperation of actions finds the greatest resolution in the financial field in relation to inter-budgetary processes. However, even here, along with the growing importance of inter- 
budgetary relations, numerous problems remain with the implementation of budget and tax reforms at the municipal level.

The financial direction of cooperation is clearly reflected in the growth of the consolidated budget and the centralization of tax revenues in the regions. In general, since the beginning of 2014, there has been a consistent increase in the consolidated budgets of the subjects of the Russian Federation in the revenues of the consolidated budget of the Russian Federation (Table 1).

Table 1. The share of the consolidated budgets of the subjects of the Russian Federation in the revenues of the consolidated budget of the Russian Federation, \%.

\begin{tabular}{|c|c|c|c|c|c|c|c|c|}
\hline & $\begin{array}{c}2010 \\
\text { year }\end{array}$ & $\begin{array}{c}2011 \\
\text { year }\end{array}$ & $\begin{array}{c}2012 \\
\text { year }\end{array}$ & $\begin{array}{c}2013 \\
\text { year }\end{array}$ & $\begin{array}{c}2014 \\
\text { year }\end{array}$ & $\begin{array}{c}2015 \\
\text { year }\end{array}$ & $\begin{array}{c}2016 \\
\text { year }\end{array}$ & $\begin{array}{c}2017 \\
\text { year }\end{array}$ \\
\hline Total tax and non-tax income & 34,6 & 37,2 & 37,7 & 33,9 & 33,3 & 33,7 & 33,3 & 36,3 \\
\hline $\begin{array}{c}\text { Tax revenues and customs } \\
\text { duties }\end{array}$ & 27,8 & 30,5 & 38,4 & 35,2 & 34,6 & 34,9 & 34,1 & 37,9 \\
\hline Tax revenue & 45,6 & 49,3 & 50,7 & 46,8 & 45,8 & 45,8 & 45,0 & 44,6 \\
\hline Non-tax income & 11,6 & 12,5 & 11,1 & 9,4 & 9,0 & 9,5 & 9,6 & 12,7 \\
\hline Expenses & 49,1 & 43,3 & 43,2 & 45,2 & 42,5 & 42,7 & 41,5 & 40,4 \\
\hline $\begin{array}{c}\text { Expenses (without inter-budget } \\
\text { transfers to extra-budgetary } \\
\text { funds) }\end{array}$ & 55,3 & 49,7 & 51,5 & 52,3 & 50,1 & 49,4 & 46,0 & 46,5 \\
\hline
\end{tabular}

The same trend in the growth and centralization of revenues to the federal budget can be traced in taxes, where own regional and local taxes and fees are consistently reduced in the specific volume of revenues of the consolidated budgets of the subjects of the Russian Federation from $27 \%$ in 2005 to $15.4 \%$ in 2017 , with a parallel reduction in regulated taxes from $56.9 \%$ to $50.8 \%$, respectively. All this indicates the increasing importance of interbudgetary relations, which are designed to ensure the effective redistribution of financial resources (Table 2).

Table 2. Structure of tax revenues of the consolidated budgets of the subjects of the Russian Federation in 2005-2017, \%

\begin{tabular}{|c|c|c|c|c|c|c|c|c|c|}
\hline Parameters & $\begin{array}{c}2005 \\
\text { year }\end{array}$ & $\begin{array}{c}2008 \\
\text { year }\end{array}$ & $\begin{array}{c}2010 \\
\text { year }\end{array}$ & $\begin{array}{c}2012 \\
\text { year }\end{array}$ & $\begin{array}{c}2013 \\
\text { year }\end{array}$ & $\begin{array}{c}2014 \\
\text { year }\end{array}$ & $\begin{array}{c}2015 \\
\text { year }\end{array}$ & $\begin{array}{c}2016 \\
\text { year }\end{array}$ & $\begin{array}{c}2017 \\
\text { year }\end{array}$ \\
\hline Income Tax income Including: & 100,0 & 100,0 & 100,0 & 100,0 & 100,0 & 100,0 & 100,0 & 100,0 & 100,0 \\
\hline Federal taxes and fees & 74,3 & 88,7 & 88,6 & 88,7 & 86,1 & 86,5 & 84,9 & 85,2 & 84,6 \\
\hline $\begin{array}{c}\text { Among them: distributed according } \\
\text { to differentiated standards }\end{array}$ & - & 2,6 & 3,6 & 3,1 & 4,6 & 4,8 & 5,0 & 4,1 & 4,2 \\
\hline $\begin{array}{c}\text { fixed by rates or standards without } \\
\text { term limits corporate }\end{array}$ & 49,6 & 74,2 & 72,7 & 73,2 & 70,7 & 69,3 & 68,5 & 69,5 & 68,9 \\
\hline $\begin{array}{c}\text { income tax at the rate regulated by } \\
\text { the subjects of the Russian } \\
\text { Federation }\end{array}$ & - & 8,7 & 8,9 & 8,7 & 6,8 & 7,7 & 6,5 & 6,7 & 6,5 \\
\hline $\begin{array}{c}\text { special tax regimes for small } \\
\text { businesses }\end{array}$ & 1,7 & 3,2 & 3,4 & 3,7 & 4,0 & 4,7 & 4,9 & 4,9 & 5,0 \\
\hline $\begin{array}{c}\text { Regional and local taxes and fees } \\
\text { Total revenues regulated by } \\
\text { regional and local authorities }\end{array}$ & 25,7 & 11,3 & 11,4 & 11,3 & 13,9 & 13,5 & 15,1 & 14,8 & 15,4 \\
\hline
\end{tabular}


Numerous problems of inconsistency of actions in inter-budgetary relations require, at a minimum, measures to increase the regions ' own financial security, including by reducing the list and size of benefits established for federal taxes and special tax regimes, the income from which is credited to regional and local budgets.

The most important control and analytical direction of cooperative interaction is the search for the shortcomings of the system elements and the replacement of the advantages of another element of the system. This approach is actively implemented in the framework of administrative reforms, one of which is the reform of regional and municipal budgets with the help of special forms of federal and regional subsidies. Experts identify a wide range of innovations in the reform of regional and municipal budgets, including: the introduction of elements of medium-term financial planning; formation of a new system of inter-budgetary relations; introduction of program-target financing principles and resultoriented budgeting mechanisms; introduction of new investment financing mechanisms, etc.

At the same time, the effectiveness of a federal or regional reform support tool does not guarantee the success of the regions and municipalities that implement these reforms. There are both difficulties in obtaining subsidies, as well as problems in implementing the stated reform programs and reporting on the resources provided. The evaluation of both the reform programs and the results of the work carried out is evaluated by a formalized set of criteria approved annually by the Ministry of Finance of the Russian Federation. At the same time, the evaluation parameters themselves are simplified in nature, and require further specification on the basis of methodological support.

In the context of significant difficulties in the existing opportunities for reforming territorial budgets, it is certainly necessary to improve the institution of support for regional and municipal reforms in the field of finance, the main of which is to specify and detail the system of analysis and assessment of the level of public finance management, in order, among other things, to increase the content component of the assessment of the implementation of reform programs

For the local level, the possibilities of developing cooperative interaction are now very relevant. At present, such elements of cooperative interaction are formed point-by-point through certain forms of cooperation. Current legislative initiatives have slightly expanded the possibilities for developing cooperation at the local level, forming several fairly significant options for such relations, including:

1. Administrative cooperation in the creation or participation of project centers. It is known that, since 2017, state authorities are called upon to create federal or regional project offices for the implementation of project management, but municipalities do not have such a duty. However, for the joint implementation of national and other projects, a number of regions began to create an environment for the development of project activities on the territory of municipalities. This activity allows you to:

- develop interpectoral and interdisciplinary methodological recommendations;

- organize training in the field of project activities;

- implement a unified project management information system for the region and municipalities;

- provide inter-budget transfers in the form of subsidies for the implementation of infrastructure projects in the territory of municipalities, etc.

A number of regions contributed to the creation and operation of a network of municipal project offices, which function in the framework of joint cooperative activities with similar structures, both in state authorities and with related divisions of the municipal administration. An example of this is the work of municipal project offices in the regions: Khanty-Mansi Autonomous Okrug, Nizhny Novgorod, Voronezh, Belgorod, Moscow, Tula, Penza, Chelyabinsk, Samara Regions, Krasnodar Territory, etc. 
2. Financial cooperation through the implementation of the powers of the LSG to provide subsidies to legal entities, etc. According to the current legislation, organizations whose founders are not MSU can receive subsidies from the local budget for activities related to reducing negative phenomena in the economy of the municipality, preventing the spread of coronavirus infection and eliminating its consequences, etc. In addition, municipalities have the right to provide "horizontal" inter-budget transfers-subsidies to other municipalities, both for the implementation of joint projects and for the financing of public facilities.

3. Control and analytical cooperation. The current legislation has changed the requirements for the annual reports of the heads of administrations on the achieved values of indicators for assessing the effectiveness of the activities of local self-government bodies (Government Resolution №953 of 16.08.2018). Now the management of the LSG is obliged to include in the reports of the results of the activities the results of an independent assessment of the quality of the conditions for the provision of services by municipal organizations. This applies to cultural institutions, health care, education, social services and other organizations of the municipality that provide services in these areas at the expense of local budgets.

As a result, the regional level of management should evaluate the results of the activities of the LSG both on the basis of the results of an independent assessment and on the mechanism for organizing this assessment. At the same time, in order to conduct an independent assessment of the quality of the conditions for the provision of services in municipal organizations, the local authorities of municipal districts and urban districts must ensure the organization and work of the public council to conduct an independent assessment of the quality of the conditions for the provision of services by organizations, providing it with appropriate legal powers and methodological recommendations. The council itself should include representatives of public organizations created to protect the rights and interests of citizens, public associations of disabled people, socially oriented NGOs, interested groups of local citizens or their initiative representatives.

However, these and other examples of cooperative interaction are very limited both in the scope of application and in the variability of relations. In any case, parallel development of centralization and cooperation in the political, financial, administrative and control aspects is necessary to form a model of a single executive vertical based on cooperative federalism, including in the aspect of local government.

\section{References}

1. M. Mukhlynina The State service and pers. 2 (2020).

2. National projects were applied to municipalities. Kommersant (2019) https://www.kommersant.ru/doc/4149166

3. V. A. Litvinov Regionology 3 (2011).

4. Meeting of the Council for the Development of Local Self-Government: http://kremlin.ru/events/councils/by-council/9/62701

5. Decision of the Council for Local Self-Government under the Federation Council of the Federal Assembly of the Russian Federation (2019). http://council.gov.ru/media/files/Arf0nAulExq8RE6dzr2olP0A9iAB333D.pdf

6. S. P. Kuznetsov Issues of state and municipal manag. 3. (2011).

7. A.V. Kurakin, N. F. Administrative and Municipal Law. 11 (2018).

8. Address of the President of the Russian Federation to the Federal Assembly of the Russian Federation 2000. 